\title{
A List of the Species of the Tribe Aphidini, family Aphidae, found in the United States, which have been heretofore named, with descriptions of some New Species.
}

\author{
By CYRUS THOMAS, Ph. D.
}

Printed Dec. 13th, 1877.

\begin{abstract}
A Sryoptical Tabie of tue Sub-families of Apindae, as given Bi Buckton.
\end{abstract}

I. Front wings with three discoidal veins, the third twice forked; hind wings with two discoidal veins.

1. Aplicitinae.

II. Front wings with three discoidal veins, third with one fork; hind wings with two discoidal veius. (One in Colopha.) 2. Schizoneurinae.

III. Front wings with three discoidal veins, all simple: hind wings with one or two discoidal veins.

3. Pemphiginae.

IV. Front wings with the third discoidal vein wanting; sometimes never acquiring wings.

4. Chermesinae.

The first sub-fanily, Aphidinae, is further divided by Backton into two tribes as follows:

I. Antennae seven-jointed,

II. Antennae six-jointed,

Tribe 1, Aphidini.

Tribe 2, Lachnini.

These characters, however, are calculated to deceive, as the sixth joint in many species of the second tribe consists of two parts, corresponding to the sixth and seventh joints in the first: in fact, the author speaks of these antennae as seven-jointed. The first of these tribes corresponds to Passerini's sub-family Aphidinae. 
Tribe 1. APHIDINI.

\section{Genus Siphonophora, Koch.}

Antennae very long, on tubercles; honey tubes long, cylindrical.

1. Siphonophora acerifoliae, new sp.

Winged, viviparous female. General color light grey, varied with white and ash-brown. Antennae extending beyond the tip of the abdomen, nearly to the tips of the wings. The three ocelli distinct. Prothorax with depressed, expanded lateral margins. From the back of each of the first three or four abdominal segments, arise two distinct, slender, somewhat curved spines. Honey-tubes not extending beyond the tip of the abdomen. Most of the veins of the front wings, especially the fourth and the forks of the third, expand at the tips, forming dusky spaces; the subcostal vein is strictly parallel with the costa; stigma short and rather small.

Basal joints of the antennae dull yellowish, with a narrow darker ring at the apex of the third and fourth joints; more or less of the fifth of a transparent whitish color, forming an annulus; sixth and seventh dusky.

Head pale brownish, with a narrow white median line; eyes red; prothorax same color as the head, with more or less distinet, very narrow, abbreviated, longitudinal white lines; abdomen marked with a few white dots somewhat regularly arranged, powdered with white behind the honey-tubes. The white lines and spots appear to be formed by a very fine white powdery substance. The spines on the abdomen black. Honey-tubes brown, white at the immediate tips.

Apterous individuals, (probably not fully grown.) Pale pea-green; eyes dark; apical portion of the antennae dusky ; tibiae dusky at the base; ho: shining.

Found on leaves of Acer dasycarpum, chiefly on the under side, somewhat sporadic and not aggregated in large colonies. Winged specimens very active and apparently eapable of leaping. Slightly above medium size, but less than $S$. rudbeckiae.

It is possible that this Aphis should be placed in Drepanosiphum, or a new genus be formed for its reception.

2. Siphonophora rudbeckiae, Fircr. Senate 30,66, 1851.

On Rudbeckia laciniata, Ambrosia trifida, and Solidago serotina.

3. Siphonophora ambrosiae, new sp.

Similar in size and appearance to S. rudbeckiae, but varying in color from a light brown to a dark seal brown.

Winged individuals. Diseoidal veins of the front wings strongly curved. Antennae passing the tip of the abdomen, light brown, dark at the apex. Honey-tubes long, cylindrical, reaching beyond the tip 
of the abdomen. Tail long and pointed. Body not tuberculate ; antennae with alternate hairs, which, under a high power, appear to be capitate.

Apterous individuals. Body more or less covered with tubercles, out of which proceed hairs, which, in some specimens at least, are capitate. A similar characteristic has been noticed by Buckton in Myzus ribis, a species found on the Red Currant and the Gooseberry.

Honey-tubes dark, or the same color as the body, tail yellowish brown. Beak dark at the tip, reaching to the third eoxae.

Found September 1st, at Sioux City, Iowa, on the leaves and flowerstems of Ambrosia psilostachya.

4. Siphonophora rosae, Reacr.

Aphis rosae, Reaum. Ins, iii, Pl. 21, Fig. 1-4.

Siphonophora rosae, Koch, Pflanz., 178.

On the tender shoots, leaf-stalks and flower-stalks of various cultivated and wild roses.

5. Siphonophora avenae, FAB.

Aphis avenae, Fab., Sp. Ins., ii, 386.

" granaria, Kirby, Linn. Trans., iv, 238.

" hordei, Kyber, Germ. Mag., Leit. ii.

" cerealis, Kalt., Mon. Pflanz., I, 16, 6.

On Wheat, Oats and Barley leaves, stems and roots, according to the time of the year.

6. Siphonophora viticola, new sp.

Apterous fencale. Rather broadly ovate, wide behind, about .08 of an inch long. Dusky brown, somewhat paler in front. Antennae scarcely as long as the body. Honey-tubes very long, slightly eurved and slightly enlarged at the base, cylindrical, and fully one-fourth the length of the body. Honey-tubes, legs and antennae black, except that there appears to be a broad pale annulus on the last near the base, and in many specimens several pale rings. Tail distinet.

Winged viviparous female. Similar to the wingless, somewhat more slender : front parts darker, the head and eentral parts of the thorax being dark brown.

The second discoidal vein more than usually distant from the third; stigma dusky or brown, elongate, with sides parallel, pointed at the tip.

In June and July, on the leaves near the tips of the branches, and also the tender twigs of cultivated grape vines.

Whether this is the Aphis vitis of Seopoli or not, I have no means at present of ascertaining.

7. Siphonophora setariae, new sp.

Winged viviparous female. Antennae about as long as the body or slightly longer: general color brown or brownish, usually with a slight 
olive tint. Subcostal vein of the fore wings parallel with the costal ; the three discoidal veins about equidistant at their bases; stigma fusiform, opaque, brown.

Apterous female. Honey-tubes extending slightly beyond the tip of the abdomen, black; tail white; legs yellow, except the joints, which are dusky; the femora are generally pale at the base. Antennae about as long as the body, marked as in the pupa, except that the light portions are clear white. Beak reaching nearly to the hind coxae.

Pupa. Oval, width about two-thirds the length; length about .05 inch. Antennae.nearly as long as the body; first and second joints dusky, third and fourth bright yellow, apex dusky. Eyes black. Wing-pads greenish at the base.

Found on the heads of Setaria glanca and Paricum crus-corvi, Carbondale, Illinois, in August.

It is possible that those found on Panicum belong to a different species, as the wingless specimens are of a lighter color, and have a distinct tubercle on the sides of the neck, which I failed to observe in those on Setaria. If it should appear that these are specifically distinct, the species may be named siphonophora panicola.

8. Siphonophora euphorbiae, new sp.

Notes in reference to color lost. If I remember rightly, it was green or greenish, similar in color to the following species, but distinct.

Antennae longer than the body, very slender; the third and seventh joints very long; a few regularly placed hairs on them. Honey-tubes long and slender, reaching beyond the tip of the abdomen, nearly onethird as long as the body, cylindrical. Tail very distinct, ensiform and slender, about half the length of the honey-tubes. Subcostal vein of the front wings diverging as it leaves the base, so as to leave the widest space between it and the costal vein opposite the insertion of the first discoidal vein, then approaching and joining it at the stigma.

Found at Sroux City, Iowa, September 1st, on Euphorbia maculata.

The specific name euphorbiae has already been used in Aphis, but this being in a different genus, it will not create confusion.

9. Siphonophora euphorbicola, new sp.

Winged viviparous female. Antennae longer than the body; general color pale pea-green; honey-tubes long, extending beyond the tip of the abdomen, equal in length to about one-fourth of the body. Head pale glaucous, the two lateral ocelli distinct; eyes dark; antennae dusky, except the basal joints and base of the third joint, which are pale. Thorax with a slight purplish tint ; prothorax green; abdomen pale green; legs hyaline. Honey-tubes pale green at base, dusky at the tips; tail long, slender, sword-shaped, greenish. Veins of the wings slender and very straight, except the stigmatic, which is strongly curved. Beak reaches the hind coxae. Length to tip of abdomen .09 inch; to tips of wings .15 inch. 
Apterous female. Pale green throughout, except the eyes, which are dark. Some specimens tuberculate.

Closely allied to $S$ 'yparissiae, Koch, but that species has red eyes.

Found at Sioux City, lowa, abont the 1st of September, on Euphorbia maryinata, on the leaves and leaf-stalks.

10. Siphonophora asclepiadis? Fiтcн. Senate, No. 30, 65, 1851 .

On Asclepias cormuti. Referred with some doubt to this species.

Dark green with dusky shadings.

11. Siphonophora erigeronensis, new sp.

Hinged viviparous, female. Green, the antennae, oyes and honeytubes black. Antennae as long as the body or rather longer; honeytubes very long, passing the abdomen, nearly. equal in length to onethird the body; cylindrical, deep black. Tail distinct, rather slender, and curved upwards. Legs long and slender, black, except the basal half of each femur, which is transparent green. Head and thorax deeper green than the abdomen.

Length to tip of abdomen, .08 inch; to tips of the wings, .13 inch. The young are pale greenish-yellow. Fully grown wingless individuals, pale pea-green.

Found in August, at Carbondale, Illinois, upon the flower-stalks of Erigeron canadensis.

12. Siphonophora coreopsidis, new sp.

Winged indiriduals. Antennae about two-thirds the length of the body; joints proportioned as usual. Honey-tubes long and cylindrical, length equal to about twice the distance to the tip of the abdomen. Head and thorax black; abdomen greenish-yellow, with a grass-green spot on the back next the thorax, and three green spots along each side, one to a segment; antennae, legs and honey-tubes black; tail the color of the abdomen. The wings present a slightly smoky appearance; costal vein, stigma and discoidal veins, very dark, almost black; subcostal with a yollowish tint

Apterous female. Head pale yellow; thorax yollowish-green; abdomen greenish-yellow, with a grass-green streak running from the thorax to the tip of the abdomen, also one running across near the thorax; the hind margin of the abdomen from the base of one honeytube to the other is of a reddish tint. Eyes black. Wing-cases of the pupa black.

Found by Mr. Th. Pergande, in October, at St. Lonis, Missouri, on Coreopsis aristosa, infesting the flower stalks.

13. Siphonophora lactucae, KaLt., Mon. Pflanz.

On the garden lettuce.

Buckton appears to think this distinct from Aphis lactucue, Linn., or S. lactucae, Kocb. 
14. Siphonophora polygoni, WaLK.

Aphis polygoni, Walk., Zool., vi, 2249.

On Polygonum persicariae.

15. Siphonophora salicicola, new sp.

I have not seen this species living, hence cannot give the colors; and I have some doubt as to its generic position, the antennal tubercles not being very distinct, and the plant on which it was found not the kind on which the species of this genus usually reside.

Winged individual. Antennae seven-jointed, of the usual form in this genus; apparently on tubercles; all the joints transversely wrinkled. Beak of medium length. Tail distinet, curved upwards, expanding in the middle, and about half the length of the honey-tubes. Honey-tubes long, reaching beyond the tip of the abdonen, cylindrical. Wings with the neuration as usual in this genus, the second fork of the third discoidal vein very near the tip, the distance to the tip not more than one-sixth the distance to the junction of the first fork with third vein.

Specimens in glycerine. Found in June, by Miss Emma A. Smith, at Peoria, Illinois, on willow.

It is evidently not the Aphis salicicola, Uhler, (A. salicti, Harr.) which is a Lachnus.

16. Siphonophora verbenae, new sp.

Wingless, female. Of a bright pea-green color throughout, (some specimens yellowish-green;) with two or three deeper green, longitudinal stripes on the abdomen. Eyes black. Antennae about as long as the body, pale and colorless, except at the tips, where they are dusky.

Honey-tubes reaching to or slightly beyond the tip of the abdomen, cylindrical, pale. Tail rather short, whitish. Body regularly ovate, somewhat elongated; medium size.

Found at Carbondale, Illinois, November, on the leaves of Verbena.

The following species are mentioned as probably found in the United States, introduced from Europe.

17. Siphonophora rubi, KaLT.

Shining green and slightly pilose. On the Blackberry.

18. Siphonophora pisi, Kalt.

Various shades of green. On the Pea.

19. Siphonoyhon tanaceti, Lins.

Brown, with lighter shades. On the common Tansy.

20, Siphonophora fragariae, Косн.

Green. On the Strawberry. 


\section{Genus PHorodon.}

Similar to Siphonophora in some respects, and to Aphis (restricted) in others. Chief distinguishing character, the spine-like prolongation of the inner side of the antennal tubercle, and of the first joint of the antennae.

21. Phorodon humuli, Schrank.

Aphis humuli, Schrank, Faun. Boic., II, 110, 1199. pruni, Mahaleb, Fonscol., Ann. Soe. Ent. Fr., X, 175.

Phorodon humuli, Passerini.

The well known and injurious Aphis of the Hop-vine; the cause of the "Blight." Green.

\section{Genus Nyzus.}

Too closely allied to Phorodon, the chief difference being that the frontal tubercles are not porrected in the female, and that the first antennal joint is only gibbous.

22. Myzus cerasi, FAB.

Aphis cerasi, Fab., Syst. Ent., 734, 4.

Myzus cerasi, Pass.

Shining black. On cherry leaves.

23. Myzus? cerasicolens, Fiтcr.

Aphis cerasicolens, Fitch, Senate, No. 30, 65, 1851.

Pale greenish yellow. On Cerasus serotina.

24. Myzus ? cerasifoliae, Fitcr.

Aphis cerasifoliae, Fitch.

Black, abdomen green. On leaves of Cerasus virginiana.

25. Myzus persicae, Sulz.

Aphis persica, Sulz, Hist. Ins., 105, Pl. II, Fig. 4, 5. institia, Koch, Pflanz., 58, Fig. 74, 75. persieaeeola, Boisd.

Myzus persicae, Pass. persicophila, Rondani.

Red and brown On the Peach and Nectarine.

26. Myzus ribis, Lins.

A phis ribis, Linn., Syst. Nat., II, 733.

Rhopalosiphum ribis, Koeh, Pflanz., 39, Fig. 50, 51.

Myzus ribis, Pass.

Green to yellow. On leaves of Red Currant. 


\section{Genus Chattophorus.}

Similar to Aphis (restricted) in form and antennae; honey-tubes very short; legs, antennae, and usually the body, hairy (hirsute).

27. Chaitophorus negundinis, new sp.

Winged individual (in glycerine).-Wings very thin and delicate, and veins very slender; the costal vein bends outward from the base to the insertion of the second discoidal vein; the stigmatic vein starts from the stigma far back near the middle, eurves slightly and grad. ually for a short distance and is then almost straight to the apex of the wing; stigma very long and slender; veins and stigma pale yellowish. Antennae nearly as long as the body, sparsely covered with long stiff hairs. Honey-tubes short. Apparently greenish.

Found at Peoria, Illinois, in June, by Miss Smith, on Negundo acervides.

28. Chaitophorus populicola, new sp.

Winged specimens. Antennae not very long, somewhat hairy. Wings transparent, but along each discoidal vein there is a broad smoky border; stigma dark; when examined by a strong power the wings appear to be covered with scales; when examined by an ordinary pocket lens they present a very pretty appearance, as though marked by dark cross bands Head and thorax shining black; neck dull yellowish; abdomen yellowish, with some irregular dusky patches toward the tip. Antenuae, which reach about the middle of the abdomen, dusky, the basal half paler; legs dark, the bases of the femora pale; beak short, reaching only to the middle coxae.

Apterous female. Reddish-brown, or tortoise-shell color ; a large, yellowish, triangular or Y-shaped spot, (the forks pointing backwards) on the middle part of the abdomen; honey-tubes reduced to simple tubercles, yellow. There is often a palish stripe along the middle of the head and thorax. Antennae pale yellowish at the base. Length about .05 of an inch

Body more or less hairy; and although my notes, made at the time, fail to mention the fact, I think that some, at least, of the apterous specimens were covered with tubercles.

Found in July, at Carbondale, Illinois, and the first part of September, at Dubuque, Iowa, on the under sides of the leaves of young sprouts of Populus angulata.

The remaining species of the tribe are placed in the genus Aphis. Those which are new and those heretofore described which 1 have been able to examine, appear to belong to the genus as restricted; the others require further examination.

29. Aphis vernoniae, new sp.

Winged individuals.-Rather small, .06 to .08 of an inch in length to the tip of the abdomen; .12 inch to the tips of the wings. General 
eral color bright lemon yellow; thorax yellow, except the lobes, which are brown or blackish; eyes black; antennae pale or dusky; abdomen yellow; honey-tubes yellow or ochreous; tail yellowish; legs pale.

In some specimens the thorax is dark: the abdomen greenishyellow.

Autennae seven-jointed, nearly as long as the body. In some speeimens (probably males) they appear to be on tubercles, whieh are prolonged on the interior margin; seventh joint about as long as the fifth and sixth united. Honey-tubes slender, cylindrical, and reaching about to the tip of the abdomen. Tail short and blunt. In some (wingless) specimens there is a distinct tubercle on each side of the prothoras, and another on each side just above the posterior coxae, but these were not observed on the winged individuals.

Wingless indivituals.-Color almost uniform greenish-yellow; eyes black; honey-tubes yellowish; tail whitish; legs pale.

Found in June, at Carbondale, Illinois, on the under side of the leaves and stems of Vernonia fasciculata; also about the first of September, at Ft. Dodge, Iowa, on the flower stalks of the same plant. The latter presented some slight differences from the former. Is closely allied to $A$. beccabungae, Koch, and possibly identical with it.

30. Aphis mali, Fabr., Syst. Ent., 337.

Aphis pyri, Reaun., Ins., III, 281,350.

On the leaves and tender twigs of the Apple.

31. Aphis malifoliae, Fitch, Fourth Rep. N. Y. S. Cab., 49.

Probably a variety of the preceding. On apple leaves.

32. Aphis cephalanthi, new sp.

Hingless female.-Of a nearly uniform purplish color, the young quite pale, the older and mature individuals darker, but more or less translucent, with a slightly pruinose cast or covering; head and tip of the abdomen dusky; a slightly impressed line along each side of the abdomen near the margin. Honey-tubes cylindrical, reaching about to the tip of the abdomen; tail distinct. Beak reaches rather beyond the middle coxae. Length about .05 inch.

They give a reddish or dull orange color when crushed.

Winged individual.--Head and thorax black, abdomen pale purplish, marked along the margin with pruinose spots. Two pruinose spots on the abdomen immediately behind the thorax; tip of the abdomen dusky; about four of the pruinose spots on each side anterior to the honey-tubes and two behind them. Antennae very slender, dusky, reaching about to the middle of the abdomen. I egs pale, except the joints and tarsi, which are dusky. Wings transparent, but with a slightly smoky shade when seen erect in the living insect; veins dark, except the subcostal or midrib, which is pale. 
Length to tip of abdomen about .05 ; to tip of the wings about .12 inch.

Found in July, at Carbondale, Illinois, on the new growth of the twigs or stems of young plants of Cephalanthus occidentalis; occasionally on the midrib of the leaf near the base.

It is possible that this should be placed in Callipterus, but the honeytubes are rather long, and the antennae do not agree with characters as given by Koch, which, in fact, appear to be contradictory.

33. Aphis viburni ? Fabr., Syst. Ent., 737, 18.

On the tender twigs of Viburnum opulus.

Our species appears to be identical with the European.

General color lilac-brown; antennae shorter than the body; the honey-tubes short; legs usually pale honey yellow. Illinois, June.

34. Aphis maidis, Fiтcu.

On the tassel, ear-stalks and roots of Indian corn. Green throughout in apterous individuals; winged with head and thorax shining black.

35. Aphis brassicae, Linn., Syst. Nat., II, 734.

Aphis floris-rapae, Curt., Journ. Roy. Agr. Soc., III, 55.

Pale greenish-yellow. On Cabbage.

36. Aphis impatientis, new sp.

Winged individucrl.-Antennae extending about to the base of the honey-tubes, pale and dusky alternately; head black; prothorax pale brown, rest of the thorax shining black; abdomen pale brownish; honey-tubes not reaching the tip of the abdomen, black; tail dull yellowish; veins of the wings and stigna brown; wings iridescent; legs dusky, tipiae pale yellow. Length to tip of abdomen about .10 inch, to tip of wings .18 inch.

Apterous specimens.-Olive or purplish-brown.

Found in August, at Carbondale, Illinois, on Impatiens fulva.

Is an Aphis in the restricted sense.

37. Aphis symphoricarpi, new sp.

Apterous individuals- No winged specimens obscrved).

There appear to be two varieties, but evidently belonging to the same colonies.

One is pale, transparent green or yellowish green ; eyes black; antennae pale, with a black ring a little beyond the middle, tips dusky; honey-tubes and a small space around the base ochre yellow; tarsi and tip of the beak black; legs pale, transparent greenish. Bodies rather 
broadly ovoid, and rery convex; abdomen very distinctly acuminate at the apex, but no tail apparent.

The other variety is rather less convex, and the dorsal surface is more or less shaded with brown; in the darker specimens this color sometimes occupies most of the back; there is usually a median line or stripe of green on the posterior half of the abdomen, which can often be indistinctly traced to the thorax; the thorax generally more or less shaded with pale brown; tip of the abdomen usually pale or greenish, and not acuminate as in the other variety; tail distinct but short, whitish; honey-tubes dark at the tips; remainder, and a space around the base, yellowish-brown.

Legs rather short. Antennae reaching to the honey-tubes or nearly to the tip of the abdomen; honey-tubes very short, almost reduced to tubercles, length about twice their diameter.

Found at Ft. Dodge, Iowa, about the first of September, on the leaves of Symphoricarpus vulgaris; on the under side of the leaves near the ends of the branches.

38. Aphis pruni, KocH, Pflanz., 68, Figs. 88-90.

Aphis prunifoliae, Fitch.

Green, with more or less black. On the leaves of native and cultivated plums.

39. Aphis rumicis, Lisw., Syst. Nat., II, 734.

For the numerous synonyms given by Walker, See Walker, List, Homop. Brit. Mus., 981. Also Trans., Ill. St. Hort. Soc, 1876, 163. Some of these synonyms are erroneous.

Black. On the Bean, Dock, \&c.

40. Aphis cornifoliae, Fiтcн. Senate, No. 30, 65, 1851.

Black. On the leares of Cornus paniculata.

41. Aphis circaezandis, Fiтcн.

Head and thorax black. On leaves of Galium circaezans.

42. Aphis crataegifoliae, Frrch. Senate, No. 30, 66, 1951 .

Black, abdomen green. On the leaves of Crataegus punctata.

43. Aphis betulaecolens, Fiтcн. Ibid.

Sulphur-yellow. On the Beech. Probably belongs to Callipterus.

44. Aphis sambucifoliae, Fiтcн. Ibid.

Black (probably greenish-black? . On Elder leaves. It is quite probable this is A. sambuci, Linn. 
45. Aphis pinizolens, Fıтсн. Ibid.

Straw-yellow. On the Pine.

46. Aphis populifoliae, Fгтсн. Ibid.

Chestnut-brown, pruinose. On leaves of Populus grandidentata. Probably belongs to Chaitophorus, and may be identical with the one one I have named Ch. populicola; but Dr. Fitch's description is too short and unsatisfactory to decide this point.

47. Aphis candicans, Fitch,

On the leaves of Populus candicans. Probably belongs to Chaitophorus.

48. Aphis gossypii, - -? Pat. Oæ. Rep., 1855.

Green or yellow, thorax striped with black. On the leaves of cotton.

49. Aphis? caryella, Fiтсн.

50. punctatella, Fiтcн.

51. maculella, Fгтсн.

52. fumi pennella, Fiтсн.

53. marginella, Fiтсн.

These species, according to Dr. Fitch, are found on the Hickory. It is more than probable that they are varieties of one species. They most likely belong to Passerini's genus Pterocallis; at any rate they belong to the tribe under consideration.

54. Aphis aceris, Linn., Syst. Nat., II, 736.

Occurs, according to Dr. Fitch, on Acer pennsylvanicum. If he is correct in his determination, it will belong to the genus Chaitophorus. The winged specimens black, the apterous yellowish and very hairy; honey-tubes very short.

\section{Genus Rhopalosiphum.}

Similar to Siphonophora, but differs in having the honey-tubes enlarged in the middle.

55. Rhopalosiphum berberidis ? Kalt., Mon. PHanz., 95.

Aphis berberidis, Fitch, Senate, No. 30, 65, 1851.

Black, abdomen yellow. On the leaves of Berberis vulgaris.

I doubt the identity of Fitch's and Kaltenbach's species, although infesting the same plant; the difference in color is too great. 
I also give descriptions of some new species belonging to other tribes, with notes on a few speeies heretofore deseribed.

Lachnus quercifoliae? Fiтсн.

The following is a deseription of what I presume to be Dr. Fiteh's L. quercifoliae.

Apterous individuals.-(apparently hardly full-grown).

Antennae longer than the body; third joint longest, the second about four-fifths the length of the third, thence deereasing regularly to the sixth, which is divided into two parts differing in diameter, or there is a seventh which is not more than half of the length of the sixth; sparsely covered with hairs placed alternately. Honey tubes very short, the diameter exeeeding the length, snowy white; tail short, semicireular; body slightly hairy. General color brown; head paler and yellowish ; first two pairs of legs transparent white ; hind legs brown, except the tarsi, which are pale. Beak whitish, and reaching slightly beyond the third coxae. The young are yellowish white, with palebrown patehes; as they increase in age, they grow darker, assuming a tortoise-shell appearanee; the middle of the back and a spot each side of the abdomen at the shoulders pale. The older speeimens show a distinct ridge along each side of the abdomen. Segments of the abdo men very distinetly marked. Nearly oval in form; length less than one-tenth of an inch. Tibiae hairy.

Found on the upper sulface of the leaves of the White Oak, at Carbondale, Illinois, in August.

I have some doubt in reference to the position assigned this species by Dr. Fiteh, if indeed it be his species.

Rhizobius eleusinis, new sp.

The body very. broadly ovate and very convex, almost globular; the abdomen abruptly rounded behind, the last segment small and eonical, appearing in the older or completely grown specimens as a short tail; tapering regularly from the middle of the abdomen forward to the head, the thorax and thoracie segments distinguished only by the deeper sutures and position. Eyes very minute, almost obsolete. Antennae very short, not reaching beyond the thorax, six-jointed, first and seeond thickest, rest cylindrical, of equal thickness ; third longest, sixth next, fourth and fifth equal in length; slightly hairy (under strong magnifier) especially the sixth joint. Beak reaching fully to the hind coxae. General and almost entire color a milky white; apical half of the antennae and tip of the beak dusky or black; the older specimens have two or three transverse fitscous bands on the thorax and posterior part of the abdomen. The under side often presents, on the lateral margins, abbreviated, transverse, brownish stripes, but the middle part is smooth and white. The legs are dirty white, more or less touched with pale brown. 
Length about .05 to .07 of an inch. The species of this genus, as far as known, never acquire wings.

Found during September, at Carbondale, Illinois, on the roots of E'leusine indica.

\section{Tychea panici, new sp.*}

Antennae very short, in the specimens examined, which appear to be scarcely fully grown; not reaching beyond the prothorax, apparently five-jointed; joints nearly equal to each other, sub-moniliform. Body ovate, very convex. Apparently without eyes, at least I failed to find them with a pretty high power, yet Mr. Pergande appears to have found specimens in which they were minutely represented, as shown in the figure drawn by him. Beak very short, reaching but little beyond the first coxae. Legs unusually short, the hind pair being scarcely longer than the others. Without honey-tubes or anything representing them. Divisions between the segments not well marked. Uniform orange red or reddish-yellow; beak tipped with fuscous. Length not more than about .04 of an inch.

Found during October, by Mr. Th. Pergande, at St. Louis, Mo., on the roots of Panicum glabrum.

This is probably a species of Tychea, which has, according to Koch, six-jointed antennae, but according to Passerini, only five.

*The winged form of this species has probably been discovered by $\mathrm{Mr}$. Pergande since the above description was printed. It apparently belongs to the genus Schizoneura. 
